\title{
How to Measure Flamenco Performer Value? A Cultural Economic Approach
}

\author{
Jesús Heredia-Carroza* ${ }^{*}$, Helena Saraiva**iD, Carlos Chavarría-Ortíz ${ }^{* * *}$
}

\begin{abstract}
This article designs an empirical methodology to measure the perceived value of the performers, specifically using the significant example of flamenco performer. The methodology is based on an Ordered Logit Model whose dependent variable is the valuation of the flamenco performer by spectators, which complements the research carried out by Heredia-Carroza (2019). The results show that virtuosity, feelings, Roma origin of the performer are significant and they have a positive effect in the valuation of it. Also, spectator's features as time consuming and number of albums acquired have a positive effect in the performer valuation. Finally, the results have a greater importance as they provide recording companies, an instrument that reduces uncertainty about the characteristics of the performer and it can also be used as a decision-making instrument for future signings of performers in record companies based on the spectators' perceptions. This methodology could be replicated for the study of other musical genres.
\end{abstract}

Keywords: perceived value; performer; Ordered Logit Model; flamenco; Popular Culture; Cultural Economics.

JEL classification: Z11.

\section{INTRODUCTION}

There is an opportunity to develop empirical researches and methodologies about the relationship between Popular Culture and its audience behaviour in its valuation (Anderson, 1993; Heredia-Carroza, Palma Martos, \& Aguado, 2021). This article applies to the example of flamenco performer, due to flamenco is a music genre included in the UNESCO Representative List of the Intangible Cultural Heritage of Humanity, since 2010.

This article takes an empirical approach to the perceived value of the flamenco performer. Based on previous research carried out by Heredia-Carroza (2019) where three valuation factors were identified: virtuosity, feelings and influencer-brand, being added new aspects valued by 586 consumers of flamenco such as: social variables of the performer and variables linked to

\footnotetext{
"Department of Economics and Economic History, Universidad de Sevilla, Spain; e-mail: jhercar12@gmail.com (corresponding author).

***Escola Superior de Tecnologia e Gestao, Politécnico da Guarda, Portugal; e-mail: helenasaraiva@ipg.pt.

**** Escuela Universitaria de Osuna, Universidad de Sevill, Spain; e-mail: cchavarria@euosuna.org.
} 
consumption profile of the spectators. After that, an Ordered Logit Model where the dependent variable is the valuation of the flamenco performer by spectators is applied. Finally, the main result shows how virtuosity, feelings, Roma origin of the performer are significant and they have a positive effect in the valuation of it. Also, spectator's features as time consuming and number of albums acquired have a positive effect in the performer valuation.

This article contributes to empiric literature on valuation of music. Concretely, the results have a greater importance as they provide recording companies, an instrument that reduces uncertainty about the characteristics of the performer and that can also be used as a decision-making instrument for future signings of performers in record companies based on the consumers' perceptions. This methodology could be replicated for the study of other musical genres.

\section{FLAMENCO SPECTATORS' PERCEPTIONS: PERFORMER'S VALUE}

Some authors analyse the impact inherent to valuation of the work and performer's capacity to infer an aesthetic experience (Cleeremans, Ginsburgh, Klein, \& Noury, 2016; Hernando \& Campo, 2017). Heredia-Carroza (2019) researched the performer's perceived value and this research looks at how flamenco spectators use their perception to value the performer in the flamenco market.

Flamenco is a traditional popular music genre with its own characteristics such as: aesthetics, performance, and socio-cultural significance, amongst others. Its wealth and variety can be observed from its three types of artistic manifestations such as cante - vocal music - toque - instrumental music - and baile - art of dancing (Heredia-Carroza, Palma Martos, \& Aguado, 2019a). However, one of the most relevant features of flamenco is its consideration as an arte vivo due to its oral tradition (Bermúdez \& Pérez, 2009). For this reason, the performers are considered as fundamental part of the creation process of the flamenco work.

Traditionally, the learning process of flamenco performers has been empirical in its three types of artistic manifestations: cante, toque and baile. Flamenco is learned through others or from sound recordings, musical scores are rarely used for this purpose (Donnier, 2011; McQueen \& Peacock, 1995). In the performance, the performer assumes a crucial role over what is written and memorised.

As can be seen, it is necessary to explain the variables that influence directly the perceived value of the flamenco performer. The aspects arising from its talent have an effect in the perceived value of the work, but also in the perceived value of the performer. This paper aims to go one step further in the valuation of the performers adding new variables to the research by Heredia-Carroza (2019) from his ad hoc data base. These variables included are, on the one hand, social variables of the performer such as: Roma origin and its age. Both of them linked with two features of flamenco: the important contribution of the Roma people to the development and plurality of flamenco (Heredia-Carroza et al., 2019a; Manuel, 2010); and the age of the performer related with deeper knowledge that older performers can reach of the flamenco performance.

On the other hand, the second group of variables are related with consumption profile of the spectators. With those control variables, the research aims to demonstrate that people with strong habits of consume flamenco, recognize the importance of the performer in traditional popular music (Heredia-Carroza, Palma Martos, \& Aguado, 2019b). Knowledge acquired 
through this paper might continue to develop the mechanism at play in flamenco spectators' perceived value of the performer started by Heredia-Carroza (2019). See Table no. 1.

Table no. 1 - Descriptive Statistics

\begin{tabular}{lccccc}
\hline Variables & Obs. & Mean & Std. Dev. & Min. & Max \\
\hline Roma origin & 577 & 2.773 & 1.978 & 1 & 7 \\
\hline Age & 579 & 2.333 & 1.764 & 1 & 7 \\
\hline Attendance frequency to flamenco shows & 586 & 3.744 & 1.843 & 1 & 6 \\
\hline Time consuming flamenco & 586 & 3.541 & 0.875 & 1 & 4 \\
\hline Number of albums acquired & 586 & 2.061 & 1.087 & 1 & 4 \\
\hline \multicolumn{7}{l}{ Own sources } & & & &
\end{tabular}

\section{METHOD}

\section{Materials and Procedure}

This paper uses the factors derived from Heredia-Carroza (2019) research: virtuosity, feelings and Influencer-Brand, adding the variables explained before: Roma origin, age, time consuming flamenco and number of albums acquired. The explained factors by HerediaCarroza (2019) were:

Table no. 2 - Results of the Exploratory Factor Analysis for spectators

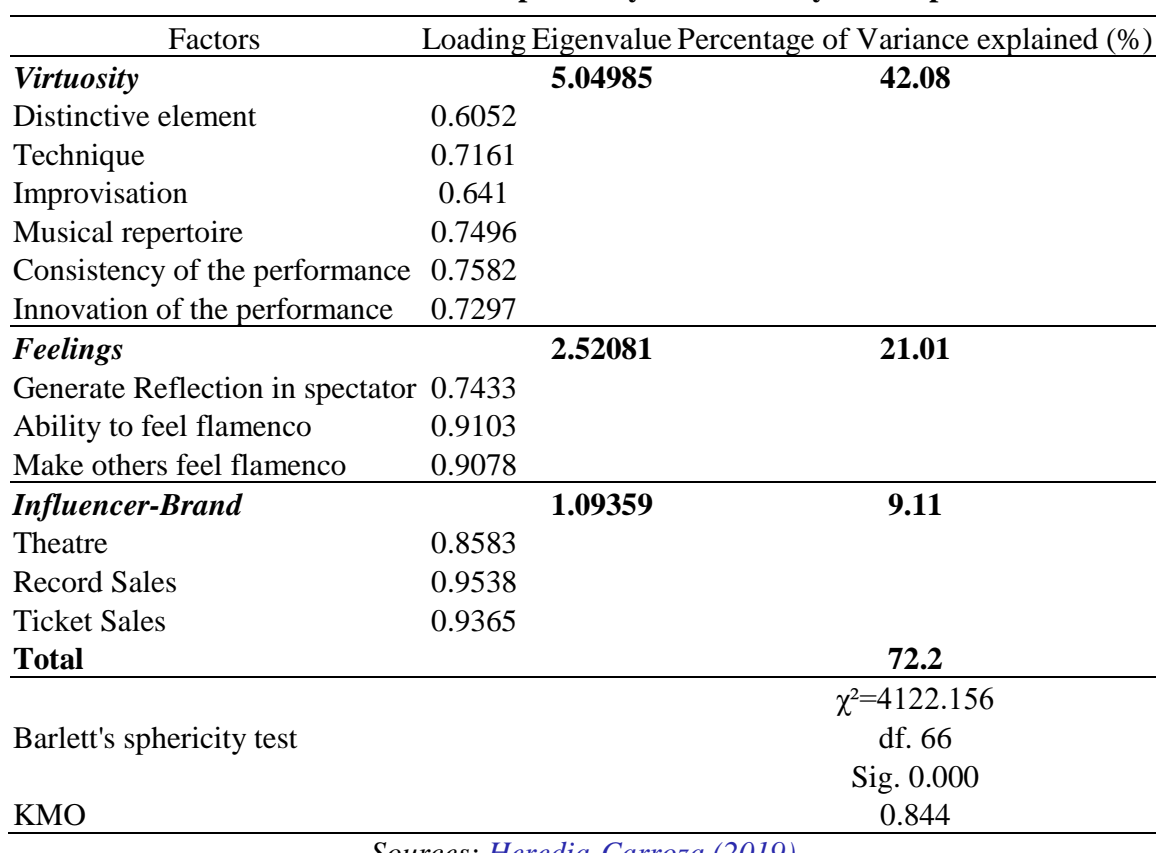




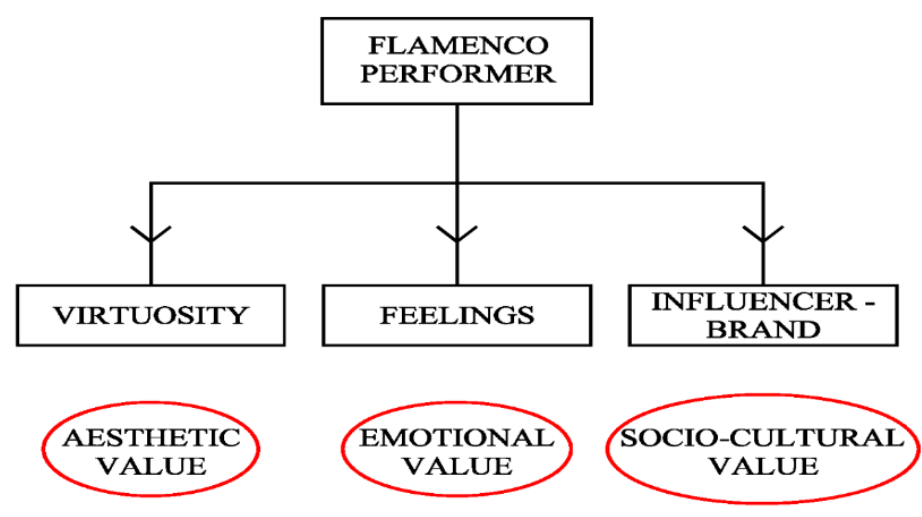

Sources: Heredia-Carroza (2019, p. 66)

Figure no. 1 - Distinguishable elements of the valuation of flamenco performers

With the ad hoc data base obtained by the surveys and the Exploratory Factor Analysis (Chan, Au, \& Ying, 2016; Choi, Papandrea, \& Bennett, 2007; Heredia-Carroza, 2019), this article aims to contrast which are the variables that determine the value of the performer. For this, the empirical strategy is the following one:

Firstly, the correlation analysis among the three factors and the new variables were analysed. These correlations are lower than 0.5 , see Table no. 3 .

Table no. 3 - Correlations among variables

\begin{tabular}{|c|c|c|c|c|c|c|c|c|}
\hline & Virtuosity & Feelings & $\begin{array}{l}\text { Influencer- } \\
\text { Brand }\end{array}$ & $\begin{array}{l}\text { Roma } \\
\text { origin }\end{array}$ & Age & $\begin{array}{c}\text { Attendance } \\
\text { frequency to } \\
\text { flamenco } \\
\text { shows }\end{array}$ & $\begin{array}{c}\text { Time } \\
\text { consuming } \\
\text { flamenco }\end{array}$ & $\begin{array}{l}\text { Number } \\
\text { of } \\
\text { albums } \\
\text { acquired }\end{array}$ \\
\hline Virtuosity & 1 & & & & & & & \\
\hline Feelings & 0 & 1 & & & & & & \\
\hline Influencer-Brand & 0 & 0 & 1 & & & & & \\
\hline Roma origin & 0.115 & 0.065 & 0.372 & 1 & & & & \\
\hline Age & -0.029 & -0.070 & 0.498 & 0.499 & 1 & & & \\
\hline $\begin{array}{l}\text { Attendance } \\
\text { frequency to } \\
\text { flamenco shows }\end{array}$ & 0.145 & 0.093 & -0.100 & 0.025 & -0.064 & 1 & & \\
\hline $\begin{array}{l}\text { Time consuming } \\
\text { flamenco }\end{array}$ & 0.146 & 0.138 & -0.159 & 0.072 & -0.097 & 0.211 & 1 & \\
\hline $\begin{array}{l}\text { Number of albums } \\
\text { acquired }\end{array}$ & 0.255 & 0.066 & -0.011 & 0.140 & -0.050 & 0.120 & 0.328 & 1 \\
\hline
\end{tabular}

Afterwards, the dependent variable of the model was identified: spectators' perceived value of the flamenco performer. That variable is expressed in a scale of 7 possible categories, where the individual chooses a path of action from a finite set of option. That way, a variable whose qualitative nature corresponds to the use of discrete choice models, so a truncated count model, such as Ordered Logit Model is configured (Atoche, 2017; De Sancha-Navarro, Palma, 
\& Oliver-Alfonso, 2019; Heredia-Carroza, Palma Martos, \& Marin, 2020; Lyashevska, Brus, \& van der Meer, 2016; Yang, Harlow, Puggioni, \& Redding, 2017). Otherwise, the Wald test combinations of the variables indicate that all of them are relevant and are correctly regrouped.

\section{RESULTS}

The results obtained via the triple Ordered Logit Model perspective are show on Table no. 4. In regard to the factors identified by Heredia-Carroza (2019) virtuosity and feelings deserve special attention, due to the influence directly to the perceived value of the performer but the influencer-brand factor is not significant in any model.

This idea focuses on the perception and recognition of the emotional and aesthetic dimensions engaged during aesthetic experience (Christensen \& Calvo-Merino, 2013; HerediaCarroza et al., 2021). So, it is plausible that flamenco spectators value exclusively the performance (virtuosity) and the emotions that they felt, they do not value the performer's brand.

They value positively its ethnic origin related with Roma. It is a very important social find, because of the flamenco spectators perceive the importance, the influence and the different way to perform of the Roma people in flamenco music. However, performer's age is not significant. Finally, the consumption habits are significant due to their importance in the deeper spectator knowledge of flamenco, as it can seen with the case of time consuming flamenco and number of albums acquired.

Table no. 4 - The probability of valuing performer

\begin{tabular}{|c|c|c|c|}
\hline & $\begin{array}{c}\text { Model 1 } \\
\text { (Score 1) }\end{array}$ & $\begin{array}{c}\text { Model 2 } \\
\text { (Score 4) }\end{array}$ & $\begin{array}{r}\text { Model 3 } \\
\text { (Score 7) }\end{array}$ \\
\hline Virtuosity & $\begin{array}{c}-0.010 * * * \\
(0.003)\end{array}$ & $\begin{array}{c}-0.045 * * * \\
(-0.009)\end{array}$ & $\begin{array}{c}0.150 * * * * \\
(0.024)\end{array}$ \\
\hline Feelings & $\begin{array}{c}-0.011 * * * \\
(0.028)\end{array}$ & $\begin{array}{c}-0.0472 * * * \\
(-0.009)\end{array}$ & $\begin{array}{c}0.155 * * * \\
(0.022)\end{array}$ \\
\hline Influencer-Brand & $\begin{array}{l}-0.002 \\
(0.002)\end{array}$ & $\begin{array}{c}-0.01 \\
(-0.008)\end{array}$ & $\begin{array}{c}0.032 \\
(0.027)\end{array}$ \\
\hline Roma origin & $\begin{array}{l}-0.003 * * \\
(-0.0013)\end{array}$ & $\begin{array}{c}-0.014 * * * \\
(0.005)\end{array}$ & $\begin{array}{c}0.045 * * * \\
(0.015)\end{array}$ \\
\hline Age & $\begin{array}{c}0.001 \\
(0.001)\end{array}$ & $\begin{array}{c}0.002 \\
(0.005)\end{array}$ & $\begin{array}{l}-0.007 \\
(0.017)\end{array}$ \\
\hline Attendance frequency to flamenco shows & $\begin{array}{c}-0.001 \\
(0.001)\end{array}$ & $\begin{array}{c}-0.003 \\
(0.0037)\end{array}$ & $\begin{array}{c}0.010 \\
(0.012)\end{array}$ \\
\hline Time consuming flamenco & $\begin{array}{c}-0.0068 * * * \\
(0.002)\end{array}$ & $\begin{array}{c}-0.0302 * * * \\
(-0.0092)\end{array}$ & $\begin{array}{c}0.099 * * * \\
(0.027)\end{array}$ \\
\hline Number of albums acquired & $\begin{array}{c}-0.006 * * * \\
(0.002) \\
\end{array}$ & $\begin{array}{c}-0.027 * * * \\
(0.008)\end{array}$ & $\begin{array}{c}0.09 * * * \\
(0.023) \\
\end{array}$ \\
\hline $\begin{array}{l}\text { Obs. } \\
\text { R2 }\end{array}$ & $\begin{array}{c}502 \\
0.123\end{array}$ & & \\
\hline
\end{tabular}




\section{CONCLUSIONS}

This article contributes to empiric literature on valuation of performers. Concretely, it continues to expands the understanding of issues related with traditional popular music following the path initiated by Heredia-Carroza (2019).

The methodology combined the exploratory factor analysis carried out by HerediaCarroza (2019) with new variables from the same ad hoc data base. And Ordered Logit Model was applied to those factors and variables, being identified the aspects that influence the perceived value of flamenco performer from the spectator perspective.

Of particular importance would be the determination as virtuosity and feelings such as the most relevant factors in the valuation of the performer, associated with the aesthetic experience of the spectator. And, other important social aspect is the recognition of the Roma origin such as a positive feature in order to value the flamenco performer.

Finally, this research has a greater importance as it provides recording companies, an instrument that reduces uncertainty about the characteristics of the performer and that can also be used as a decision-making instrument for future signings of performers in record companies based on the consumers' perceptions. This methodology could be replicated for the study of other musical genres.

\section{Acknowledgements}

This paper was presented on I Workshop on Popular Culture Economics and Management (WPCEM) held in Escuela Universitaria de Osuna (Spain, June 2021). The author is grateful with the organization of WPCEM and Dr. Ovidiu Stoica for many helpful discussions and comments, as well as with all the interviewed experts, the organizations which disclosed the survey: Flama. La guía del Flamenco, Centro Andaluz de Documentación del Flamenco and the website Promocionmusical.com, and finally with the people who took the survey.

\section{ORCID}

Jesús Heredia-Carroza (iD https://orcid.org/0000-0003-2280-2680
Helena Saraiva (D) https://orcid.org/0000-0003-1734-1250
Carlos Chavarría-Ortíz (iD) https://orcid.org/0000-0002-6608-5276

\section{References}

Anderson, E. (1993). Value in Ethics and Economics. Cambridge: Harvard University Press.

Atoche, P. (2017). Modelos de regresión con datos de conteo: aplicación a competiciones deportivas. Retrieved from https://idus.us.es/xmlui/handle/11441/63085

Bermúdez, S., \& Pérez, J. (2009). Introduction: Spanish Popular Music Studies. Journal of Spanish Cultural Studies, 10(2), 127-133. http://dx.doi.org/10.1080/14636200902990661

Chan, M. K., Au, W. T., \& Ying, C. (2016). Developing Validating a Theater Experience Scale. Empirical Studies of the Arts, 35(2), 169-193. http://dx.doi.org/10.1177/0276237416662737

Choi, A. S., Papandrea, F., \& Bennett, J. (2007). Assessing cultural values: Developing an attitudinal scale. Journal of Cultural Economics, 31(4), 311-335. http://dx.doi.org/10.1007/s10824-0079045-8

Christensen, J. F., \& Calvo-Merino, B. (2013). Dance as subject for empirical aesthetics. Psychology of Aesthetics, Creativity, and the Arts, 7(1), 76-88. http://dx.doi.org/10.1037/a0031827 
Cleeremans, A., Ginsburgh, V., Klein, O., \& Noury, A. (2016). What's in a Name? The effect of an Artist's Name on Aesthetic Judgements. Empirical Studies of the Arts, 34(1), 126-139. http://dx.doi.org/10.1177/0276237415621197

De Sancha-Navarro, J. M., Palma, L., \& Oliver-Alfonso, M. D. (2019). Explanatory factors of university student participation in flamenco. Economics \& Sociology (Ternopil), 12(4), 130-148. http://dx.doi.org/10.14254/2071-789X.2019/12-4/8

Donnier, P. (2011). Descripcion multimedia del flamenco. ?Un nuevo medio de transmision oral? In J. M. Diaz-Banez \& F. J. Escobar Borrego (Eds.), Investigacion y flamenco (pp. 83-95): Signatura.

Heredia-Carroza, J. (2019). Flamenco Performer's Perceived Value: Development of a Measurement Index. Scientific Annals of Economics and Business, 66(SI2), 59-71. http://dx.doi.org/10.47743/saeb-2019-0017

Heredia-Carroza, J., Palma Martos, L., \& Aguado, L. F. (2019a). Flamenco y Derechos de Autor. El caso de Camaron de la Isla. Arbor, 195(791), a496. http://dx.doi.org/10.3989/arbor.2019.791n1009

Heredia-Carroza, J., Palma Martos, L., \& Aguado, L. F. (2019b). Song, performance and authorship: The case of flamenco in Spain. Trames. A Journal of the Humanities and Social Sciences, 23(73/68). http://dx.doi.org/10.3176/tr.2019.1.01

Heredia-Carroza, J., Palma Martos, L., \& Marin, A. (2020). Determinants of attendance frequency to flamenco shows. Revista de Metodos Cuantitativos Para La Economia y La Empresa, 29, 79-98. http://dx.doi.org/10.46661/revmetodoscuanteconempresa.3751

Heredia-Carroza, J., Palma Martos, L. A., \& Aguado, L. F. (2021). How to Measure Intangible Cultural Heritage Value? The Case of Flamenco in Spain. Empirical Studies of the Arts, 39(2), 149-170. http://dx.doi.org/10.1177/0276237420907865

Hernando, E., \& Campo, S. (2017). Does the Artist's Name Influence the Perceived Value of an Art Work? International Journal of Arts Management, 19(2), 49-58.

Lyashevska, O., Brus, D. J., \& van der Meer, J. (2016). Mapping species abundance by a spatial zeroinflated Poisson model: A case study in the Wadden Sea, the Netherlands. Ecology and Evolution, 6(2), 532-543. http://dx.doi.org/10.1002/ece3.1880

Manuel, P. (2010). Composition, Authorship, and Ownership in Flamenco, Past and Present. Ethnomusicology, 54(1), 106-135. http://dx.doi.org/10.5406/ethnomusicology.54.1.0106

McQueen, H. L., \& Peacock, A. (1995). Implementing performing rights. Journal of Cultural Economics, 19, 157-175. http://dx.doi.org/10.1007/BF01074203

Yang, S., Harlow, L. L., Puggioni, G., \& Redding, C. A. (2017). A comparison of different methods of zero-inflated data analysis and an application in health surveys. Journal of Modern Applied Statistical Methods ; JMASM, 16(1), 518-543. http://dx.doi.org/10.22237/jmasm/1493598600

\section{Copyright}

This article is an open access article distributed under the terms and conditions of the

Creative Commons Attribution-NonCommercial-NoDerivatives 4.0 International License. 